\title{
Psychosemiotic Approach to Comprehension, or a Sense Text Model
}

\section{Nikitina Elena Sergeevna}

Psycholinguistics Department, RAS Institute of Linguistics, Moscow, Russia

\section{Email address:}

m1253076@yandex.ru

\section{To cite this article:}

Nikitina Elena Sergeevna. Psychosemiotic Approach to Comprehension, or a Sense Text Model. International Journal of Language and Linguistics. Vol. 6, No. 1, 2018, pp. 15-19. doi: 10.11648/j.ij11.20180601.13

Received: October 5, 2017; Accepted: February 6, 2018; Published: March 2, 2018

\begin{abstract}
As a sign formation, text is fundamentally heterogeneous and heterostructural. Since the times of classical rhetoric, three layers have been identified in the text: the object layer, the logical layer, and the language layer. Each had relative independence, which enabled them to be the subject of analysis in a special section of the rhetorical canon. These layers were characterized by their own descriptive logic and ways of processing the material. Sense configuration could proceed in three directions under the influence of three molecular structures of the text: language, logic, theme. Hence, the possibility of three ways of understanding: literal, conceptual and paralogical. However, writing allowed dialogue with the text ("conversation with a book"), i.e. interacting with it as with a subject of communication and trying to understand the sense of the text as of the one which carries the sense of its self measure. The three ways of comprehension - the three semantic systems - must be coordinated, correlated to one another in order to appear as a semantic whole - the face of the text.
\end{abstract}

Keywords: Text, Sense, Spatial Focusing of Sense, Comprehension

\section{Introduction}

Text as an object of understanding

Text is not oral speech fixed on paper but a special variety of speech creation having its own parameters different from oral speech parameters. I. R. Galperin defines text as a specific "organizing islet", or an ordered form of communication devoid of spontaneity. "It is a result of speech creating process, characterized by completeness, objectified in the form of a written document, processed in accordance with the type of this document, a work consisting of a title (headline) and a number of special units (superphrasal units), united by different types of lexical, logical, grammatical, stylistic connection, having a certain focus and pragmatic setting [1]. Only in the written form, the dismemberment of the text, explicitly expressed graphically, is revealed as the result of deliberate processing of a linguistic expression. Therefore, text as a sign is not linear and is devoid of spontaneity. Its significant feature is semantic completeness. Reality "converted" into signs, i.e. a text, was constituted as an object of study after an extremely rigid selection of relevant characteristics [2].

When considering the concept of text in terms of the semiotics of culture, it was discovered that, in order for any message to be defined as a "text", it must be at least twice encoded. First, as a message and, secondly, as a metamessage, as related to genre unity, a conscious notion of something as a communicative message. Yu. Lotman wrote that "a message defined as "law" differs from a description of a certain criminal case in that it simultaneously belongs to both natural and legal language, constituting in the first case a chain of signs with different values, and in the second, a certain complex sign with a single value. The same can be said about such texts as "prayer", etc."[3].

For a philologist, text is an "invisible deep essence", which is reconstructed by abstracting from sensually perceived data. For semioticians - "text is the field of methodological operations" [4], a special kind of metalanguage activity for restoring the meanings of the text. In contrast to the utterance, the text lives in socio-cultural time and space, germinating in their meanings.

With the formation of writing, the text acquired an additional function: it became not only a store of experience, an instrument for influencing others, but also a substitute for the meaning-generating subject in communication - it took on the function of comprehending the experience recorded in 
it. The text has become a quasi-subject of communication. And this quasi-subject requires a special relationship: an understanding of its organization. Understanding is a process of recreating the semantic essence of the text. From the text you can extract information, content, the author's intention, emotional tension, language colouring, linguistic and other errors. But the essential characteristic of a text is its senses. Texts are stores of senses.

\section{Understanding as Revealing Text Content}

The very phenomenon of understanding is stipulated by the dual role of any knowledge. On the one hand, it involves fixing a certain experience, on the other, it is the result of the actualization of certain goals, tasks and fragments of experience, to which knowledge refers. From this second side, knowledge serves as an evaluation filter for all subsequent cognition. Therefore, understanding is not reducible to description, explanation, systematization and other functions of scientific knowledge, it is inseparable from the evaluation activity of consciousness.

Each level of knowledge is an understanding insofar as it contains an aspect of evaluation. Understanding is a process of cognizing reality through the prism of certain normativevaluative systems of social practice.

Sense genesis (the process of generation and multiplication of senses) can be viewed from the standpoint of procedural actions as understanding of the text and its interpretation. Once J. Piaget proposed to break the process of adaptation (the ability of a living organism to adjust to changes in the environment) into two interrelated but counter directional procedures: assimilation and accommodation. According to Piaget [5], assimilation is a conservative process in the sense that its main function is to convert the unknown into the familiar, to reduce the new to the old. A new assimilating system should always be just a variety of the previously acquired one, and this ensures both the gradualness and continuity of intellectual development. The essence of accommodation is the process of adaptation to the various requirements put forward to the individual by the objective world. In some cognitive acts, the assimilation component is relatively predominant; in others there is a great propensity to accommodation. But never in the process of cognition there is "pure" assimilation or "clean" accommodation; intellectual acts presume to a certain extent the presence of both. Cognitive acquisition of reality always implies simultaneously assimilation produced by the structure and accommodation of this structure.

While there are monographs published about understanding of the text, including the one by the author of this article [6], the mechanisms of interpretation were given less attention for the reasons of playful and epiphenomenal nature of interpretational structures. New interpretations appearas accompanying satellites of other "pictures of the world": theories, paradigms, prejudices, translations into other languages, or borrowing texts from other cultures. According to Piaget's scheme, the text can be assimilated (included in a different context) and one can accommodate to the text (enter the context offered by it). Assimilation is constructing and the construction is organization. This is "pulling" the event to the template structure that the individual possesses at the moment. It results in a new sense. Interpretation is the use of a ready-made meaning for a new situation. To express a new sense, a new text has to be created. Only in this case there will be a shift of meaning within a new communicative field. The text will always be an intermediary in the semantic shift.

Subjective relation to the text assumes, undoubtedly, accommodation as an initial stage in communication, i. e. transition to the text positions. But how is this possible? Only if synthesis - understanding of the text is the result of its analysis. And such an analysis, in which the meaning of the text is decomposed not into elements, but into units, into semantic variants of the text. It is impossible to collect the sense of the text from meanings - integrity does not arise from separate elements. A unit is such integrity, which contains all the salient properties of the semantic structure of the text.

Sense is a function of content in a communicative situation, moreover, it is a function that is expressed by speech, passed through the ISSUE of misunderstanding.

\section{Sense Foci of the Text}

Since the content of the text is always a world reflected with regard to the addressee and the same (source, canonical) texts, the senses can also be existential, analytical (similar to others), pragmatic (influencing). Compare the sections in semiotics: semantics, syntactics, pragmatics. Once again. The meaning is the function (why?) of the content in communication. The function does not decompose into elements. Therefore, if we begin to apply linguistic units, we will necessarily come out only onto content, onto objectivity. Sense leads us to relationships - in the broadest sense of the word, and not only in the psychological version ("how do you treat me?"). The function organizes the content, tailoring it to its "meaning" as the style of a dress in accordance with its purpose. Senses do not "stick" to the content, they specify its structure.

Beginning to understand the text, by default we accept that as a mandatory communicative component (quasisubject), it contains its own sense. After all, there is always a lot in the text that the author did not put into it. First, due to the fact that he uses the means of language - the main accumulator of human experience. Secondly, a reader, introducing their own situation into the dialogue, sees in the text sometimes more or something different from the author. Thirdly, the text for the reader in principle can not be exhausted in the semantic sense, something in it will inevitably remain not understood, therefore, incomprehensible. The text is enveloped in an intonational-value context, which varies according to epochs, worldviews, concepts. 
The guarding mechanism of the boundaries of the text is precisely the dilution of the processes of understanding and interpretation. If Hermeneutics did this on the basis of a goal/medium, in the psychosemiotic approach it is done on the principle of external/internal: the internal space of the text or the space of the communicative situation, where the text exists as a semantic object. Interpretations are done on the basis of understanding. To interpret, you first need to understand what is the text about, that is, to engage in dialogue with the text, enter the hermeneutical circle. First goes understanding: highlighting the meaning of what is in the text, and then - interpreting it in the light of the emerging external communicative task. Understanding is the procedure of accommodation, interpretation is that of assimilation. Otherwise, the text can be assimilated (included in another context as an element) and the text can be accommodated (enter the context offered by itself).

Classical rhetoric arranged the semantic coordinates of the text in three vectors of its effect on the listener: ethos, logos, pathos. These coordinates are simultaneously the three basic functions of the content of the text in the aspect of its relation to Truth, Kindness and Beauty. They also form contextual configurations of the communicative situation. Ethos, pathos and logos are in communication with each other and the message is constantly monitored on these three aspects. The content of the text in the space of these coordinates forms functional, otherwise, semantic foci. Therefore, any text includes the meaning of being (ethos), typological (logos) and communicative (pathos).

\section{Semantic Text Space}

As a quasi-subject, the text is opposed to the reader. "Humanitarian thought is born as a thought about other people's thoughts, wills, manifestations, expressions, signs, which are manifestations of gods (revelation) or people (laws of rulers, commandments of ancestors, nameless utterances and riddles, etc.). Scientifically accurate, so to speak, passportization of texts and critique of texts are later phenomena (this is a regular revolution in humanitarian thinking, the birth of distrust). Initially, a belief that requires only understanding, i.e. interpretation. $<\ldots>$ Whatever the goals of the researcher, only the text can be the starting point" [7].

The text can act as the initiator of communication. It puzzles you, you can not understand it, even knowing the languages of communication. Here it is not the subject of ridicule, bullying, criticism, not an instrument of influence, but a partner or teacher."In every epoch, in every social circle, in every little world of a family, friends and acquaintances, comrades in which a person grows up and lives, there are always authoritative, tone-setting utterances, artistic, scientific, journalistic works, which are relied on and referred to, which are quoted, imitated, followed by. In every epoch in all areas of life and activity there are certain traditions expressed and preserved in verbal attire: in literary works, in utterances, in sayings, etc. There are always some verbally expressed leading ideas of "rulers of thoughts" of this era, some basic tasks, slogans, etc. I am not talking about school textbook examples with which children learn their native language and which, of course, are always expressive" [7]. In some historical periods books were burned as dissenting subjects.

Today, discussions go on about which 10, 100, 500 works of fiction should be included in the list of compulsory reading for modern man as the formers of their world outlook. Without communication with the text, consciousness can not pulsate.

\section{Origen on Text Sense Structure}

The Greek Christian theologian and philosopher Origen likened text to a person consisting of a body, soul and spirit a triune and indivisible entity. And therefore in the text, according to Origen, you can find three senses. The essence of his teaching goes down to the assertion that - by analogy with the three-part composition of a person representing the unity of the "body", "soul" and "spirit" - in Scripture one can see "corporal", "soulful" and "spiritual" senses. And as soon as the process of spiritual perfection of man and mankind can be conceived as a gradual overcoming of the material principle and the attainment of a "spiritual" state, then, respectively, the revelation of the true meaning of Scripture must imply a consistent transition from "corporeal" meaning to a more sublime "soulful", and the to the "spiritual". Also, Origen specifies that the "body" of Scripture should be understood as its "letter", i.e. the direct and literal meaning of what is said in the Bible, that the "soulful" meaning are the moral instructions contained in the Scripture, however they are not proclaimed in a direct and self-evident form, but, as it were, indirectly, through the implied, and therefore requiring a deviation from the flat "literal" understanding of the text, and, finally, that the "spiritual" meaning of Scripture is the highest, mystical meaning of the Christian dogma [8].

Subsequently, this subdivision was transferred to secular texts. From this doctrine, interpreting it in modern terms, one can deduce, that:

1. Text is a sign with its own content.

2. Senses are hidden behind words and they need to be recreated.

3. There are several (at least three) senses coexisting in the text simultaneously.

4. Sense is a cell - an indivisible unit of text understanding, which develops in the direction of a higher abstraction: from the image to the concept and then to the idea.

5. The sense should be understood through certain cognitive procedures that are not available to all and more indirect stages of understanding require special "dedication" or, training, to put it simply.

6. The sense is always dialogical, if it is considered as a cell (an integral and indivisible unit) of understanding. If we do not understand something, we return the text to the addressee with the words: "if I understood you correctly, you 
had the following on your mind" and then you retell the text. The text (sense) lives only when it comes into contact with other texts (senses). Understanding is the correlation with other senses and rethinking in a different context: in the present, past or future. M. Bakhtin interpreted this as the stages of dialogical understanding of the movement: "the starting point is the given text, the movement backward is past contexts, moving forward is the anticipation (and the beginning) of the future context" [7].

7. The text as a subject sets boundaries or norms of understanding, controlling procedures of understanding through its constituents.

\section{The Dialogical Nature of Understanding}

Understanding is a rather late formation of consciousness and it is associated with the sign mediation of knowledge, moreover, such mediation, where there is no one-to-one relationship between the sign and the object being replaced (as, for example, in the index or symbol).

Understanding is such a procedure of consciousness that replenishes a separate action to a complete formation. It is an act of mastering spiritual meanings, those beginnings in objects and phenomena of culture that are not given to us in perceptions.

The only way to master the meanings is to understand them. For the act of understanding, not only the sign is necessary but also the Other, to whom this sign needs to be explained to include it into the system of joint knowledge. Otherwise, understanding is both a cognitive and communicative act.

As a regular accompaniment of cognition, it emerged in the age of writing. After all, the printed word is a certain stoppage of the mental movement, a kind of "freeze frame," which allows us to return to the beginning and correlate it with the result even in the process of the movement itself. Understanding is manifested through the opening of a "point of view" as a single and homogeneous space in dialogic interaction [9].

Embodied in the letter, the word broke away from its original connection with the sound, turned into a spatial thing, became a "body". And it continued its journey around the world without an author. Having survived the author, the text does not need the author's comments, entering into a dialogue with other texts. So, no reader, unless he is an expert, looks at the content of the text he reads as an expression of the identity of another person. For them it is only a hull of a huge and integral body of knowledge, which should be perceived as a piece of knowledge that was once obtained by one person from another. And this chain goes back to antiquity. Equally, the author, writing down certain information, did not intend to evoke in future readers an interest in his person. The text became a mediator, the subject of a communicative act. It carries not just information about certain events, but also the purpose (sense) of transmitting this information in a certain time interval - in a specific communicative situation. The restoration of this "intention" of the text is its semantic aspect. Understanding is the act of recreating semantic relationships, as opposed to material relations. But beyond objectivity sense does not exist.

\section{Conclusion}

Text is a three-layer formation featuring three realities: the world of the objective, the world of the imaginative and the language world. For each layer, a sphere of analysis was proposed by semiotics: semantics, syntactics, and pragmatics. In each sphere, certain units of analysis and types of links are formed, their own structures of the text being. If semantics and syntactics reveal the objective logical relations of the content in the text, pragmatics turns to the value-telic aspects of it, to what Saussure called the significance." Sense is a unit of the pragmatic aspect of textual analysis. We get the text meaning by adding a relative coordinate to the content and doing this through the language. The text crystallizes subjective relations meanings, turning the latter into a communicative subject. And so we can say that the text has its own voice, its intentions, its meaning, independent of either the author or the readers. The text can self-address, entering metacommunication, this procedure can be called selfdebugging of the text, when everything falls into place and then the text is ready for dialogue, i.e. for entering the text space. The feeling of perfection of the text is familiar to many writers, when there is nothing to add and nothing to correct.

If we approach the text as a sign with its own content, then it obeys the principle of triplicity of the sign structure. The sign, as a triune object, also reflects life in itself. In spite of the fact that the three components of the sign are not reducible to each other, but each has its own specificity, each performs its "work", which is not inherent in other parts, through "triune" and "indivisibility" they interact with each other forming a single whole - "consubstantiality" [10]. In the absence of one of the components, the other two replace, replenish its functions, holding the sign in a semantic unity. This is possible, due to such a property of the sign as its significance or value within other sign systems. The sign is systemic. That is why its functioning within the system allows one to focus understanding within the text itself.

The meaning of the text can be distributed into three layers or contours of consciousness, where only one text is built at a time. And the reason for this is precisely the "relative" component of meaning. Besides, the text is just one of the current communication characters. It lives in the communicative space. Without the addresser, addressee, communication channel, communicative situation, the text can not exist - it does not have points of support. The text does not just depend on its environment in communication, it is formed under its influence. Thus, focusing on the addresser forms the text as an influential, instrumental entity. Focusing on the subject - as an objective, reflective or constructive 
formation. Focusing on the addressee characterizes the text as a generative device or literary work. But also the text can be focused on itself - and then it acts as a unit of communication - molecular integrity, or, the subject of communicative interaction.

Semantic transformations of the text through the change of contextual components allow the reader to enter a reflexive position regarding the range of their own understanding. And, thus, to enter a dialogue with other points of view, pushing apart the boundaries of one's consciousness.

\section{References}

[1] Gal'perin, I. R. Tekst kak obyekt lingvisticheskogo issledovanija. Monografija/I. R. Gal'perin. - M.: Nauka, 1981. $140 \mathrm{~s}$.

[2] Ginzburg K. Mify - jemblemy - primety: Morfologijaiistorija. Sb. statej/Per. s it. iposlesl. S. L. Kozlova. - M.: Novoe izdatel'stvo, 2004. $348 \mathrm{~s}$.

[3] Lotman, Ju. M. Semiotika kul'tury I ponjatie teksta// Istorija I tipologija russkoj kul'tury/ Ju. M. Lotman. - SPb.: Iskusstvo SPB, 2002. S. $158-162$.

[4] Bart, R. Ot proizvedenija k tekstu//Bart R. Izbrannye raboty: Semiotika: Pojetika: Per.s fr./ R. Bart. - M.: Progress. 1989. S. 413-423.

[5] Piaget, J. The development of object concept: The construction of reality in the child /J. Piaget.- New York: Basic Books, 1954. Pp. 3-96.
[6] Nikitina, E. S. Smyslovoj analiz teksta: Psihosemioticheskij podhod/E. S. Nikitina.- M.: LENAND, 2016. $200 \mathrm{~s}$.

[7] Bahtin, M. M. Problema teksta v lingvistike, filologii i drugih gumanitarnyh naukah. Opyt filosofskogo analiza//Jestetika slovesnogo tvorchestva/M. M. Bahtin. - M.: Iskusstvo, 1979. $424 \mathrm{~s}$.

[8] Origen. O nachalah. Protiv Cel'sa. Kn. 4 (Po izdaniju Kazanskoj Duhovnoj Akademii, 1892)/Origen.-SPb. Bibliopolis, 2008. $792 \mathrm{~s}$

[9] Mak-Ljujen, Marshall. Galaktika Gutenberga: Sotvorenie cheloveka pechatnoj kul'tury/M.mak-Ljujen. - Kiev: NikaCentr, 2004. $432 \mathrm{~s}$.

[10] Raushenbah. B. V. Logika troichnosti / B. V. Raushenbah // Voprosy filosofii. -1993- № 3. S. 63-70.

\section{Biography}

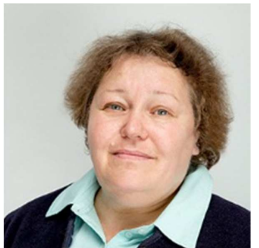

Nikitina Elena Sergeevna; Candidate of Philology, Associate Professor; Leading researcher of the Institute of Linguistics of the Russian Academy of Sciences; Area of interest: semiotics, psycholinguistics, communication theory, psychohermeneutics, 